\title{
Kebiasaan Mengkonsumsi Tuak dan Persepsi Sehat Masyarakat Desa Bukit Selamat Kecamatan Besitang Kabupaten Langkat Propinsi Sumatera Utara
}

\author{
Nina Fentiana ${ }^{1}$ \\ ${ }^{1}$ Kesehatan Masyarakat, Fakultas Farmasi dan IImu Kesehatan USM-Indonesia, \\ Lantai 2 Gedung Baru Jalan Kapten Muslim No 79 Medan 20128, Indonesia \\ Correspondence email: fentiana.nina@gmail.com
}

\begin{abstract}
Abstrak. Tuak adalah minuman beralkohol tradisional di daerah Sumatera Utara, terutama pada suku Batak Toba, yang mengandung alkohol dengan kadar $4 \%$. Tuak terbuat dari batang kelapa atau batang aren dan diambil airnya kemudian dicampurkan dengan raru (llyas, 2013). Minum tuak merupakan bagian tradisi yang telah menjadi turun temurun di Desa Bukit Selamat dan sangat sulit di hilangkan dari kebiasaan masyarakat. Padahal alkohol bisa menimbulkan dampak yang serius terhadap kesehatan yaitu mabuk, berat badan naik, tekanan darah tinggi, sistem kekebalan tubuh menurun, kanker, penyakit jantung, gangguan pernapasan dan gangguan hati. Tujuan penelitian untuk mendeskripsikan kebiasaan minum tuak dan persepsi sehat masyarakat Desa Bukit Selamat. Jenis penelitian adalah deskriptif menggunakan metode eksploratif. Peneliti ini dilakukan di Desa Bukit Selamat Kec. Besitang Kabupaten Langkat dengan mengumpulkan data dari 92 orang responden. Kebiasaan minum tuak masyarakat Desa Bukit Selamat adalah kategori berat sebesar $84,8 \%$ dengan $55,4 \%$ tergolong baru meminum tuak. Masyarakat dengan persepsi sehat yang negative sebanyak $66,3 \%$. Ada hubungan antara persepsi sehat dengan kebiasaan mengkonsumsi tuak masyarakat Desa Bukit Selamat.
\end{abstract}

Kata kunci: Alkohol; Minuman Tradisional; Kesehatan

\begin{abstract}
Tuak is a traditional alcoholic beverage in North Sumatera area, especially in Batak Toba, containing 4\% alcohol. Tuak made from coconut or palm stem and taken water then mixed with raru. Drinking tuak is part of tradition that has become hereditary in the village of Bukit Selamat and very difficult to remove from the customs of society. Though alcohol can cause serious health effects of drunkenness, weight gain, high blood pressure, decreased immune system, cancer, heart disease, respiratory problems and liver disorders. The objective of the study was to describe the drinking habits of tuak and healthy perception of Bukit Selamat Village community. The research type is descriptive using explorative method. The researcher was conducted in Bukit Selamat Village Kec. Besitang Langkat District by collecting data from 92 respondents. The habit of drinking of tuak of Bukit Selamat Village is weight category $84,8 \%$ with $55,4 \%$ classified as new drink of palm wine. People with negative healthy perception were $66.3 \%$. There is a relationship between healthy perception with the habit of consuming tuak of Bukit Selamat Village community.
\end{abstract}

Keywords: Alcohol; Tuak; Health

\section{PENDAHULUAN}

Minuman beralkohol tradisional merupakan salah satu jenis minuman yang marak dibeberapa wilayah Indonesia. Minuman ini dibuat dan dikemas secara sederhana serta sering dijadikan sebagai jamuan diacara adat, misalnya minuman cap tikus dari Manado dan Minahasa, Ballodari dari Makasar, Sopidari dari Maluku dan sekitarnya, Arak Bali dan lain sebagainya (llyas, 2013). Tuak adalah minuman beralkohol tradisional dari Sumatera Utara. Tuak terbuat dari batang kelapa atau batang aren dan diambil airnya kemudian dicampurkan dengan raru yang mengandung alkohol dengan kadar 4\% (Institue Of Alcohol Studies, 2013).

Tuak sampai sekarang masih menjadi kegemaran muda-mudi daerah Batak Toba dan Simalungun sebagai minuman penghangat tubuh dan di waktu adanya pestapesta di malam hari. Sebagai tradisi yang telah menjadi turun temurun sangat sulit di hilangkan dari kebiasaan masyarakat. Tuak dibuat secara konvensional, sehingga tidak diketahui dengan pasti kadar alkohol dan jumlah sel ragi Saccharomyces tuak di setiap proses produksi. Sehingga tuak yang diminum secara berkelanjutan dapat mengganggu kesehatan peminumnya karena pengaruh buruk alkohol yang dapat menyebabkan mabuk, berat badan naik, tekanan darah tinggi, sistem kekebalan tubuh menurun, kanker, penyakit jantung, gangguan pernapasan dan gangguan hati (Institue Of Alcohol Studies, 2013).
Masyarakat Desa Bukit Selamat sebagian besar bermata pencaharian bertani. Setiap malam setelah pulang dari sawah atau ladang kaum laki-laki langsung ke warung tuak atau yang lebih dikenal dengan lapo tuak, untuk meminum tuak yang disertai dengan tambul (sejenis cemilan) yaitu daging celeng, ular, anjing dan biawak baik itu dijadikan sop atau digoreng. Biasanya mereka meminum tuak sambil bernyanyi dengan diiringi gitar, bercerita membahas masalah adat, kondisi ladang, politik, maupun masalah-masalah yang terjadi di Desa Bukit Selamat.

Studi pendahuluan menunjukkan masyarakat Desa Bukit Selamat minum tuak dengan jumlah yang lebih dari satu gelas bahkan lebih dari 3-4 gelas untuk sekali minum. Biasanya mereka membeli tuak per teko, satu teko bisa berisi 6 gelas tuak. Bahkan kebanyakan dari mereka mengkonsumsi tuak sebelum makan, padahal kandungan alkohol dalam tuak tersebut cukup besar, dan masyarakat yang mengkonsumsi tuak secara berlebihan sering mengalami perut terasa mual dan mulut terasa kering.

\section{METODE PENELITIAN Desain Penelitian}

Jenis penelitian yang digunakan adalah penelitian deskriptif dan menggunakan metode eksploratif dan bertujuan untuk mengetahui persepsi masyarakat tentang sehat dengan kebiasaan mengkonsumsi tuak di Desa Bukit Selamat. 


\section{Populasi dan Sampel}

Populasi dalam penelitian ini adalah seluruh kepala keluarga yang bertempat tinggal di Desa Bukit Selamat tahun 2017 sebanyak 1136 KK. Jumlah sampel ditentunkan dengan menggunakan perhitungan rumus Slovin dan diperoleh total sampel dalam penelitian adalah 92 sampel.

\section{Pengumpulan Data}

Data dikumpulkan dengan wawancara menggunakan kuesioner. Wawancara tentang persepsi masyarakat tentang sehat dengan kebiasaan mengkonsumsi tuak menggunakan 30 pernyataan, dengan pilihan jawaban kepada responden dengan jawaban Setuju skor 1 dan Tidak setuju skor 0 . kebiasaan mengkonsumsi tuak diajukan 3 pertanyaan dengan menggunakan alat ukur berupa gelas ukur dalam satuan $\mathrm{mL}$. Untuk mengetahui lama mengkonsumsi tuak di kategorikan berdasarkan interval kelas (kuartil).

\section{Analisis Data}

Analisis data menggunakan uji Chi Square dengan batas kemaknaan (alpha) $=0,05$ dan 95\% confidence Interval (Setiadi, 2010).

\section{HASIL DAN PEMBAHASAN}

Kebiasaan mengkonsumsi tuak masyarakat Desa Bukit Selamat disajikan pada tabel 1 dan persepsi sehat disajikan pada tabel 2.

Tabel 1. Kebiasaan Mengkonsumsi Tuak Masyarakat Desa Bukit Selamat

\begin{tabular}{llcr}
\hline No & Kebiasaan konsumsi tuak & $\mathbf{f}$ & $\%$ \\
\hline 1 & Ringan & 3 & 3,3 \\
2 & Sedang & 11 & 12,0 \\
3 & Berat & 78 & 84,8 \\
& Total & 92 & 100,0 \\
\hline
\end{tabular}

Tabel 2. Persepsi Sehat Masyarakat Desa Bukit Selamat

\begin{tabular}{llcr}
\hline No & Persepsi tentang sehat & f & $\%$ \\
\hline 1 & Positif & 31 & 33,7 \\
2 & Negatif & 61 & 66,3 \\
& Total & 92 & 100,0 \\
\hline
\end{tabular}

Kebiasaan minum tuak masyarakat Desa Bukit Selamat kategori berat sebanyak $84,8 \%$ dan mayoritas baru memiliki kebiasaan minum tuak $(55,4 \%)$. Sebanyak $66,3 \%$ masyarakat Desa Bukit Selamat memiliki persepsi tentang sehat yang negatif. Hasil uji chi square tentang tabulasi silang persepsi sehat dengan kebiasaaan mengkonsumsi tuak diperoleh nilai $\rho$ value $=$ $0,019<0,05$ artinya ada hubungan antara persepsi sehat dengan kebiasaan mengkonsumsi tuak.

\section{Pembahasan}

Masyarakat di Desa Bukit Selamat memiliki jumlah penduduk 4.404 orang dan jumlah kepala keluarga (KK) 1.136 orang, dengan mayoritas beragama Islam sebanyak $88 \%$. Mayoritas suku di Desa Bukit Selamat adalah suku Batak sebanyak $46 \%$, masyarakat suku batak memiliki kepercayaan terhadap tuak yang merupakan suatu perilaku atau tindakan seseorang terhadap khasiat tuak. Khasiat tuak yang banyak dipercayai oleh peminum tuak di Desa Bukit Selamat adalah sebagai minuman yang meningkatkan semangat, menyegarkan dan menyehatkan badan, selain itu untuk mempererat kekerabatan, para peminum tuak juga menyebutkan alasan mereka mengkonsumsi tuak adalah untuk melepaskan beban atau masalah sehingga mendorong masyarakat untuk mengkonsumsi tuak.

Dimasyarakat Desa Bukit Selamat dijumpai hambatan dalam penerapan kesehatan dalam kehidupannya. Hal ini dapat dilihat dari perbedaan persepsi sehat pada masyarakat di daerah ini. Adanya perbedaan persepsi tentang sehat yang timbul dimasyarakat sangat di pengaruhi oleh sikap, perhatian, dan faktor dari luar seperti perekonomian masyarakat tersebut dan lain sebagainya (BPOM RI, 2014). Hal ini dapat ditinjau dari karateristik masyarakat di Desa Bukit Selamat dengan rata-rata pendapatan per bulan sekitar 1.000.000-3.000.000 (57,6 \%) yang menunjukan tingkat perekonomian masyarakat Desa Bukit Selamat adalah menengah kebawah.

Persepsi negatif yang dominan pada masyarakat di Desa Bukit Selamat Kecamatan Besitang tentang kebiasaan mengkonsumsi tuak dikarenakan oleh faktor historis keberadaan tuak tersebut yang sampai saat ini berpengaruh sangat besar (Haryanti, 2012 dan Wiers, R \& Dkk. 2002). Dari segi ekonomi masyarakat di Desa Bukit Selamat yang dihargai Rp.5000/ gelas dianggap salah satu minuman jenis alkohol yang terjangkau. Mengkonsumsi tuak dianggap tidak begitu berpengaruh pada penurunan kesejahteraan masyarakat di Desa Bukit Selamat. Mengkonsumsi tuak sudah menjadi kebiasaan masyarakat di Desa Bukit Selamat sehingga karena sudah menjadi kebiasaan bagi masyarakat, dengan alasan minum tuak dapat menyehatkan tubuh, dan memberikan keakraban bagi masyarakat agar lebih dekat lagi satu sama yang lain.

Sehat adalah keadaan keseimbangan yang sempurna baik fisik, mental dan sosial, tidak hanya bebas dari penyakit dan kelemahan (WHO,1947) dan UU Pokok kesehatan no. 9 tahun 1960). Pengertian sehat ini dipersepsi oleh 92 responden $(100 \%)$ yaitu semua responden pada penelitian ini. Hal tersebut menyatakan bahwa masyarakat di Desa Bukit Selamat sudah mengetahui pentingnya kesehatan dalam kehidupan masyarakat di Desa Bukit Selamat dan juga termasuk dalam ciri-ciri masyarakat sehat untuk hidup sehat menurut Mubarak (2009) yaitu adanya peningkatan dari kemampuan masyarakat untuk hidup sehat, mampu mengatasi masalah kesehatan yang sederhana, berupaya meningkatkan kesehatan lingkungan, selalu meningkatkan status gizi masyarakat berkaitan dengan peningkatan status social ekonomi masyarakat, dan berupaya selalu menurunkan angka kesakitan dan kematian dari berbagai sebab dan penyakit. Penjelasan ini didukung juga oleh penelitian Hutagalung (2014) terkait dengan persepsi masyarakat tentang sehat dengan kebiasaan mengkonsumsi tuak di Desa Meat kecamatan Tampahan Kabupaten Toba Samosir yang hasil penelitiannya masyarakat berpersepsi positif sebanyak 30 orang (75\%) dan negative sebanyak 10 orang $(25 \%)$ dan Persepsi 
masyarakat terhadap kebiasaan mengkonsumsi tuak adalah mayoritas berpersepsi negatif .

Pada dasarnya masyarakat di Desa Bukit Selamat sudah menyadari pentingnya kesehatan dalam kehidupannya. Akan tetapi masih dapat dijumpai hambatan dalam penerapan kesehatan dalam kehidupannya. Hal ini dapat dilihat dari perbedaan persepsi masyarakat tersebut. Adanya perbedaan persepsi tentang sehat yang timbul dimasyarakat sangat di pengaruhi oleh sikap, perhatian, dan faktor dari luar seperti perekonomian masyarakat tersebut dan lain sebagainya (Siagian 1995). Hal ini dapat ditinjau dari karateristik masyarakat di Desa Bukit Selamat Kecamatan Besitang yang rata-rata responden 1.000.000-3.000.000 sebanyak 53 orang( $57,6 \%)$. Hal ini menjelaskan bahwa masyarakat desa Bukit Selamat perekonomiannya masih menengah kebawah.

Berdasarkan hasil penelitian bahwa dilihat dari 31 responden, yang memiliki persepsi tentang sehat positif dengan lama mengkonsumsi tuak kategori baru sebanyak, 9 orang $(9,0 \%)$, sedang 10 orang $(10,9 \%)$ dan kategori lama sebanyak 13 orang $(13,0 \%)$. Sedangkan dari 61 responden yang memiliki persepsi negative dengan lama mengkonsumsi tuak kategori baru sebanyak 3 orang $(3,3 \%)$, sedang 5 orang $(5,4 \%)$ dan lama sebanyak 53 orang $(66,3 \%)$. Hasil uji statistik dengan menggunakan uji chi square tentang tabulasi silang persepsi sehat dengan lama ,mengkonsumsi tuak diperoleh nilai $\rho$ value $=0,000<0,05$ artinya ada hubungan antara persepsi sehat dengan lama mengkonsumsi tuak.

\section{SIMPULAN}

Hasil penelitian menyimpulkan kebiasaan minum tuak Desa Bukit Selamat adalah kategori berat sebanyak $84,8 \%$. Ada hubungan antara persepsi sehat dengan kebiasaan mengkonsumsi tuak masyarakat Desa Bukit Selamat.

\section{DAFTAR PUSTAKA}

BPOM RI. 2014. Topik Sajian Utama:Menilik Regulasi Minuman Beralkohol Di Indonesia. Info PomVol.15 No 3 Mei-Juni 2014.

Gramenzi, A. Dkk. 2006. Review Article: Alkoholic Liver Diases-Phatophsiological Aspects And Risk Factor Alimentary $P$ Harmchology And The Repelitic Volume 24 Pp.1151-1161.

Haryanti, P \& Dkk. 2012. Aplikasi Pengawet Alami Nira Kelapa Bentuk Serbuk Berbahan Sirih Hijau Terhadap Sifat Fisik Dan Kimia Gula Kelapa. Jurnal Pembangunan Pedesaan, Desember Volume 12.

llyas, S. 2013. Evaluasi Kualitas Spermatozoa Dan Jumlah Mencit (Ms Musculus L) (F1) Setelah Pemberian Tuak. Prosiding Semirata FMIPA Universitas Lampung.

Institute Of Alcohol Studies. 2013. Alcohol Consumption Factsheet. Jakarta:Salemba Medika.

Maass, Linda T. 2004. Kesehatan Ibu Dan Anak:Persepsi Budaya Dan Dampak Kesehatannya. Fakultas Kesehatan Masyarakat Universitas Sumatera Utara.

Marzuki. 2012. Tradisi Dan Budaya Masyarakat Jawa Dalam Perseptif Islam.
Maulana, H. D. Promosi Kesehatan. Jakarta:Egc.

Mubarak, W. I (2009) Sosiologi Untuk Keperawatan Pengantar Dan Teori.

Noorkasiani \& Dkk. 2007.Sosiologi Keperwatan. Jakarta. Egc.

Noviyanti, Rizky. 2014. Pengaruh Konsumsi Minuman Tuak Terhadap Erosi Gigi Di Kecamatan Maiwa Kabupaten Enrekang. Fakultas Kedokteran Gigi Universitas Hassanuddin Makasar.

Riyanto, Agus. 2011. Aplikasi Metodologi Penelitian Kesehatan. Nuha Medika,

Sesso, H. D. 2008. Alkohol Consumption And Risk Of Hypertension In Women And Men.American Heart Association, Inc, Hal 1080-1087.

Setiadi, 2010. Metodologi Penelitian Kesehatan. Graha IImu,Jakarta.

Simamora, B. 2008. Panduan Perilaku Konsumen. Jakarta: Pt.Gramedia.

Sinda, F \& Len. 2003. Peranan Kulit Bali Sonneratia Sp, Dalam Fermentasi Nira Aren Menjadi Minuman Beralkohol. Marina Chimica Acta, April. Vol 1

Teo, Albert. S. T. Dkk. 2011. Pengaruh Pemberian Virgin Coconut Oil (Vco) Terhadap Kadar Trigliserida Penderita Diabetes Melitus Di Blu RSUP. Prof Dr.R. Di Kandal Manado.

Utina, S. S. 2011. Alkohol Dan Pengaruhnya Terhadap Kesehatan Mental.

WHO,2014. Global Status Report On Alkohol And Health. Switzerland:L'iv Comsari, Villiars-SounsYens.

WHO, 2015. Diabetes Miletus Dari http://www.who.int, Media Centre/Factsheets/Fs138/En/.

Wiers, R \& Dkk. 2002. Impliat And Explicit AlkoholRelated Cognitions In Heavy And Light Drinkes .Journal Of Abnormal Pyschology 2002, Vol lii No.4 P.648-658. 